Original Research Paper

\title{
Developing Crisis Management Model for Second-Tier Banks in the Post-Crisis Period of Economy Development in the Republic of Kazakhstan
}

\author{
${ }^{1}$ Leile Syzdykovna Komekbayeva and ${ }^{2}$ Yerkenazym Dulatovna Orynbassarova \\ ${ }^{I}$ Faculty of Economics, Chair of Finance, E.A. Buketov KSU, Karaganda, the Republic of Kazakhstan \\ ${ }^{2}$ Faculty of Economics, Chair of Finance, E.A. Buketov KSU, Karaganda, the Republic of Kazakhstan
}

\author{
Article history \\ Received: 19-01-2016 \\ Revised: 19-04-2016 \\ Accepted: 05-05-2016 \\ Corresponding Author: \\ Leile Syzdykovna \\ Komekbayeva \\ Faculty of Economics, Chair of \\ Finance, E.A. Buketov KSU, \\ Karaganda, the Republic of \\ Kazakhstan \\ Email: goodletter77@mail.ru
}

\begin{abstract}
In the context of an ineffective crisis management system, the development of the banking sector of Kazakhstan in the post-crisis period is characterized by the impaired financial stability of second-tier banks. This situation creates the threat of systemic risk in the national banking system as a result of the critical slowdown in economy crediting by $49.5 \%$ and a reduction in bank assets by $47.2 \%$ of GDP. The article develops a diversified model of anti-crisis management aimed at increasing the financial stability of commercial banks. In contrast to other studies, the author's approach is based on the argumentation of cause and effect links of financial, social and technical anti-crisis measures, the subordination of tactical objectives, which will provide an optimal level of financial stability of banks. Achieving the optimal level of financial stability of banks will determine the maximum rate of development of the national banking system in the post-crisis period. The objectivity and accuracy of the results is an advantage of this approach, it takes into account the specificity of the post-crisis period of the banking system functioning and is consistent with the international practice of strategic management.
\end{abstract}

Keywords: Banking System in the Post-Crisis Period, Crisis Management System, Financial Stability of the Bank, Business Processes of the Bank, Bank's Client Base, Bank Staff

\section{Introduction}

The banking sector of the Republic of Kazakhstan is of paramount importance in the process of cash flow in the economy of the country. Moreover, in terms of ensuring the formation of gross domestic product of the state by $50.2 \%$, sustainability and stability of the banking system functioning is of strategic importance for the economic development of Kazakhstan (ABRK, 2013; MNERK, 2015). Enhanced liberalization orientation of the financial system of Kazakhstan until 2007 determined intensification of the RK banking sector to carry out operations in the international loan markets for replenishing liabilities. As a consequence, the gross external debt of commercial banks as of 2007 amounted to about half of the total external debt of Kazakhstan, while the share of short-term liabilities to non-residents was $53.3 \%$ of total liabilities of the second-tier banks. In this regard, in the context of the economy overheating in Kazakhstan in 2007 the national banking system was the first to be affected by the global mortgage financial crisis, due to the impact of which the growth rate of the Kazakhstan economy crediting decreased by $44 \%$ from 2007 to 2008 (NBK, 2015).

The inefficiency of the system of anti-crisis management of commercial banks in Kazakhstan and the functioning modern models of strategic management predetermined the weak dynamics of their development and violation of financial stability in the post-crisis period-from 2008 and up to now.

Reduced financial stability of the second-tier banks causes the threat of systemic risk in the national banking system and susceptibility to the negative effects of the external destructive factors in the post-crisis period, which in turn determines the preservation of the low level of bank lending to the economy Kazakhstan. Meanwhile, the modern financial system of Kazakhstan is characterized by the absolute dominance of bank lending as a source of generating temporary free funds for economic entities in the national economy. In this 
regard, in the conditions of the almost complete lack of alternative sources of raising additional capital the decrease in the efficiency of the banking system determined the post-crisis decline in the level of the economy development in Kazakhstan. In this context, a fundamental factor in increasing lending to the national economy is to ensure the development of the national banking system by improving the efficiency of the second-tier banks.

The aim of the article is to develop approaches to improve anti-crisis management in the second-tier commercial banks with a view to ensuring their financial stability as a factor in the development of the banking system and the economy.

\section{Main Objective and Hypotheses of the Study}

The general objective of this study is to develop a model of anti-crisis management in the RK second-tier banks providing development of the national banking system in the post-crisis period.

The specific objective is to determine causal and logical links and tactical tasks comprising the anti-crisis management systems, ensuring achievement of the optimal level of financial stability of the second-tier banks in Kazakhstan and conditioning maximum rates of growth of the RK banking sector in the post-crisis period.

These are hypothesized in the following two hypotheses:

- If we define the structural and logical chain of all components of the anti-crisis management system, it is possible to provide such a level of financial stability of the second-tier banks, which promotes intensive development of the national banking system in the post-crisis period

- If we quantify the optimal levels of financial stability performance of the second-tier banks, it is possible to maximize growth rates of the national banking system by implementing the tactical sociotechnical purposes of anti-crisis management

\section{Review of the Relevant Literature}

Scientific search in improving the system of anticrisis management of commercial banks is one of the most relevant scientific fields in the concept of strategic management of organizations, due to active processes of globalization and formation of the conditions of uncertainty in the development of the banking system (Ibrahim, 2016; Kravchenko, 2015; Zhu et al., 2015).

As evidenced by the analysis of the economic literature, most scholars consider the banks' anti-crisis management as a system of measures aimed at overcoming or preventing the crisis state, manifested in insolvency, bankruptcy and unprofitability of the economic entity. It involves also forecasting of crisis situations and development of the crisis deterrence and fast forward strategies and in conditions of crisis-the neutralization or minimization of its effects (Rakhmetova, 2015; Fernández et al., 2013). Nevertheless, such understanding of anti-crisis management does not entirely characterize the essence of the banks' anti-crisis management from the perspective of the banking sector role for the economic development of the country. In the economies of those countries, which are characterized by the bank-oriented model of financial relations, stability and efficiency of the banking system predetermines and ensures the development of the national economy (Jovanovic and Petreski, 2014; Ahrend and Goujard, 2015). Kazakhstan, as already mentioned, refers to such countries, too. This in turn necessitates to base in the framework of anti-crisis management not only on the activities aimed at maintaining the financial stability of the banking sector to prevent systemic risks, but also to ensure its sustainable development as a fundamental factor in the growth of the country's economy (Fiedor, 2014). Therefore, in this study the anti-crisis management system in the banking sector is understood as a system of methods to ensure the strategic balance between the objectives and the abilities of the bank in the changing market conditions, the strengthening of its financial stability and provision of its sustainable development in the short and long term.

Implementation of the strategic goal of anti-crisis management in the banking system is carried out on the basis of methods for diagnosis of the bank's financial condition and the methods for the crisis prevention (Frey and Kerl, 2015). The financial analysis is based on the evaluation of financial stability of commercial banks (Ritz and Walther, 2015). The methodology of financial stability evaluation and monitoring in the bank's anticrisis management system is characterized by the diversity of approaches and variability of their application (Markman and Venzin, 2014). The most common approach includes coefficient analysis system (BAKIS).

The main advantage of this method is the availability of information support, ease of calculation and interpretation of indicators (Mayer, 2013; Asmild and Zhu, 2015). However, this conceptual approach has a significant drawback in practice: A quantitative assessment of the values of financial coefficients, exceedance of which reflects the threat of reducing financial stability, based on the account of regularities existing in the world practice. However, national accounting systems and such systems as IFRS or USGAAP, UKGAAP are based on different values of almost all financial indicators of banks (Kašparovská et al., 2014; Marchenko, 2010). This is determined by the peculiarities of the methodology of the asset value formation and sources of their financing in the format of each of the specified systems. Therefore, the cost of the same named assets will be ambiguous. 
In the banks' anti-crisis management system rating systems are widely practiced, the main ones of them are: PATROL, ORAP, CAMEL (Vazquez and Federico, 2015). Despite the popularity of these approaches to bank monitoring the ratings are based on expert (subjective) estimates of the bank financial stability and are characterized by the ambiguity of the obtained results (Kuchukova et al., 2013; Bhat and Ryan, 2015). Ambiguity arises when processing expert opinions and is expressed in the selection of the optimal method of aggregation of expert evaluations (Caggiano et al., 2014). In addition, the performance evaluation unreliability is conditioned by probability of subjective opinions of experts and limitation of their judgments about financial stability. Therefore, in many respects the quality of the final result depends on the professionalism of the representatives of the supervisory authorities.

Comprehensive banking risk assessment systems (RATE, RAST) and statistical models (FIMS, SAABA) in the methodology of anti-crisis management are aimed at assessing the risk level assumed by the bank (Frey and Kerl, 2015), that is why they are based on the determination of only the current financial state of the bank (Ritz and Walther, 2015) and also are characterized by complexity of practical application.

It should be noted that despite the advantages and demand for most common approaches to anti-crisis management in the banking practice, these methods also have common flaws in their application. First, they give a fairly approximate assessment of the bank's financial stability, since the coefficients are calculated based on the balance sheet figures. Whereas for the most accurate reflection of the results it is required to focus on the market value of balance sheet items of commercial banks (Zhu et al., 2015). Secondly, the assessment of the financial stability of banks is based on consideration only of normative values of financial indicators prescribed in Basel II, III (Marín Hernández et al., 2015) or the prudential standards of the national banking activity. Such approach ignores the subjectivity factor in the establishment of financial stability coefficient values and the objective need for periodic review of these values due to changes in the macro- and microeconomic situation. Therefore, the main issue here is the extent to which compliance with mandatory standards and assessment factors really guarantees the reliability of the bank and provides the potential for its development.

The second component of the anti-crisis management system in the banks consists of the methods to prevent the crisis, which lie in the development of anti-crisis measures to restore the financial stability of banks. The main anti-crisis areas include provision of capital adequacy and profitability of the bank, improving asset quality, loan and deposit portfolios and the increase in the bank's liquidity (Frey and Kerl, 2015). The advantage of these approaches is a directivity aimed at improving the financial condition of the bank. However, such an approach is focused solely on the domestic economic factors that had caused the crisis in the banking system, although in reality the latter are multifactorial. One cannot deny, for example, that clients' dissatisfaction and inefficient business processes in the bank have a significant impact on the worsening crisis manifestations in the banking activity (Bigeldyieva et al., 2014). Moreover, as noted by the scholars, the social and technical implementation of the strategic objectives in the system of anti-crisis management of the financial superstructure is a superstructure to achieve and ensure the financial stability of the bank (Ahrend and Goujard, 2015). Therefore, the orientation of the system of anti-crisis management in banks only on accounting the economic threats will be aimed rather at limiting the negative effects of the crisis than at combating the root causes of the organization's crisis state. Later on this will become a destabilizing factor of the fullfledged development of the banking system and may provoke a systemic crisis.

Referring to the shortcomings of the conceptual approaches to resolving the problems of this scientific field, the aim of the study is designated to develop a conceptual approach to the improvement of the anticrisis management system in the banking sector. Since the strategic objective of anti-crisis management is based not only on the restoration of financial stability of the banking sector, but also on ensuring its development, the anti-crisis management system should be diversified in its nature, based on the equilibrium and subordination of economic and socio-technical tactical purposes.

Considering that the modern banking system of Kazakhstan is characterized by inefficiency of anti-crisis management, the activity of the RK second-tier banks in the post-crisis period aimed at developing a diversified model of the anti-crisis management system served as an object of research.

\section{Results}

The diversified model for anti-crisis management in the RK second-tier banks in the post-crisis period has been developed as a strategy, based on the strategic chart techniques. The strategic charts are based on the balanced system of indicators and are universal for any interpretation of the strategy. The advantage of implementing the strategic charts is that they take into account the priorities of tactical objectives at the bank aimed at achieving the general purpose of anti-crisis management, i.e., at achieving the growth of the financial sustainability at banks to ensure the development of the national banking sector.

The technique of developing the strategic chart involves determining the tactical objectives in four blocks of development: Staff, business-processes, clients and finances (Kolbin, 2015). According to the technique, the chart is designed "top down", where the basic factor 
is represented by the bank staff. Solving the strategic issues within the system of staff will facilitate implementation of the tactical tasks within the system of the bank business techniques, which, in its turn, will ensure realization of the tactical tasks in streamlining the client base. Accomplishing the aggregate of social and technical purposes will help achieve the tactical target of the financial block, namely, the improvement in financial sustainability. This, consequently, will secure realization of the strategic target in the second-tier banks in Kazakhstan i.e., ensuring the development of the national banking sector in the post-crisis period.

In each block of the anti-crisis management strategic chart (according to the technique), the anti-crisis methods (tactical targets) together with the indicators for their evaluation are determined by applying the expert method.

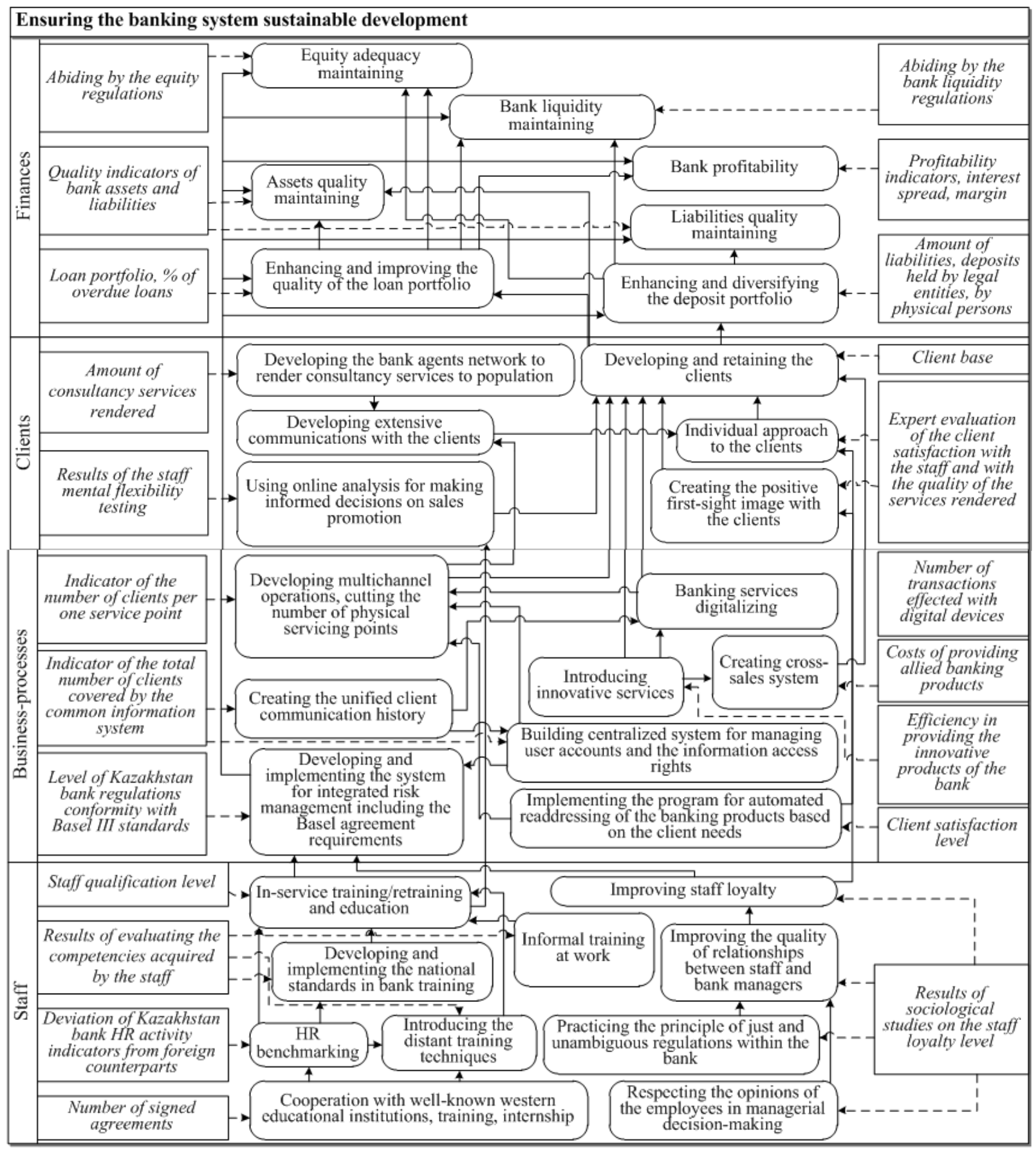

Fig. 1. Strategic model for anti-crisis management in the RK post-crisis banking sector 
To formulate the list of the tactical targets and to create the balanced system of indicators to evaluate the degree of achieving the targets and to define their cause and effect links, Delphi method has been applied in this study (Kolbin, 2015). Twenty experts, which is the optimum number for an expert group according to this method, have been questioned by e-mail. A basic list of tactical targets, which was supplemented and corrected in the process of the anonymous interviewing, has been presented before the experts. As such, the members of the boards of the most financially stable and profitable banks of Kazakhstan have been selected: Halyk Bank JSC, Tsesnabank JSC, Citibank of Kazakhstan JSC, KASPIBANK JSC, Altyn Bank JSC, Asia Credit Bank JSC. The conceptual diversified model for the anticrisis management in the post-crisis RK banking sector is shown in Fig. 1.

Since the anti-crisis management in the second-tier banks should ensure the development of the national banking system, the tactical task blocks of the strategy chart should guarantee the definite optimum level of financial stability of banks to promote the development in the post-crisis period. Therefore, within the framework of this study, the critical levels of the financial stability basic indicators have been identified for the RK second-tier banks in the diversified model for anti-crisis management, ensuring maximized development of the banking sector in the post-crisis period.

In this study, for the purposes of defining the critical levels of the financial indicators in the anti-crisis management model for Kazakhstan commercial banks, the system of indicators has been expertly created, which most precisely reflects the state of financial stability in the anti-crisis management system of 38 second-tier banks: Capital adequacy ratio (k1-1); capital adequacy ratio $(\mathrm{k} 2)$; ratio of maximum risk exposure per borrower, associated with the bank special relationships $\left(\mathrm{k} 3{ }^{\prime}\right)$; ratio of maximum amount of bank's investment (k6); ratio of maxim limit of short-term liabilities to non-residents of RK (k7); ratio of bank's capitalization to liabilities to non-residents of RK $(\mathrm{k} 8)$, the loan portfolio volume; the total commitment amount; amount of retail deposits; amount of corporate deposits; amount of performing assets (net); net remuneration related income; level of banks' interest margin and interest spread.

Those indicators have been established by disaggregating the general indicators used for evaluating the tactical targets in "finance" block within the diversified model for the anti-crisis management.

The statistical sampling period was 2008-2014, the post-crisis period in the banking sector development. Given the fact that the statistic base is backed by the financial reporting of the second-tier banks in the RK, the period of investigation is limited by 2014 due to the lack of the bank balance sheets for 2015 .
In as much as the methodological approach is focused not only at determining the financial stability, but also at ensuring the banking sector development in the post-crisis period, the integral quotient of the intensity of alterations in the financial indicator system of the second-tier banks has been selected as the summarizing indicator of the RK banking sector development. This approach is based on the concept of the direct dependency existing between the financial stability level of the banks and the progress of the banking sector development (Dungey and Lestano, 2015).

To calculate the integral indicator of the national banking sector development, a sampling of the financial indicators has been formed based on the growth rates of the abovementioned financial stability indicators in the secondtier banks of Kazakhstan. Since the level and the value of the financial indicators do not affect the development of the national banking sector in the same way, in this study, the priorities of these effects have been identified applying the principal components method to ensure the best possible calculation of the integral indicator.

Applying the principal components method (multivariable factor analysis) the factor loadings of the financial stability indicators have been determined in the model for the anti-crisis management in the second-tier banks together with the priorities of their effects on Kazakhstan banking sector development in the post-crisis period:

$W j \Rightarrow F i$

Where:

$W j=$ A variable (growth rate of the second-tier bank financial stability indicator)

$\mathrm{F} i=$ The factors (components), common for all variables

The components are measured by generating a linear combination as a model of connection between the primary variables and the components:

$V_{i}=A_{i, 1} F_{1}+A_{1,2} F_{2}+\ldots .+A_{i, k} F_{k}+U$

Where:

$V_{i}=$ The value of $i$ variable, expressed as a linear combination of $k$ common factors

$A_{i, k}=$ Regressive quotients, representing the input contribution of each of $k$ factors into this variable

$F_{l . k}=$ The factors, common for all variables

$U=$ The factor, characteristic for variable $V_{i}$ only

Each factor $k$ is expressed as a linear combination of the observable variables:

$F_{j}=W_{j, 1} V_{1}+W_{j, 2} V_{2}+\ldots+W_{j, p} V_{p}$ 
Where:

$W j .1=$ The loadings of $j$ factor at $i$ variable, or, factor loadings

$p \quad=$ The number of variables (Khalafyan, 2014)

The results of calculating the factor loadings applying Statistic a 10 software are given in Table 1.

The number of the factors (principle components) of the second-tier bank financial stability indicators in the post-crisis period has been determined by calculating the eigen-values of the principle components based on Keiser criterion. The components with eigen-values $>1$ were considered. As a result, 4 principal components have been identified for the factor loadings of the growth rate of the second-tier banks financial indicators at the RK banking sector development (Table 2). The priorities of the effects of the financial stability factors on the RK banking sector development in the post-crisis period are characterized by the cumulative dispersion as follows:

$I_{d b}=\sum_{1}^{j} F_{j} \times C v_{j}$

Where:

$I_{d b}=$ An integral indicator of the second-tier bank financial stability in the anti-crisis management model
$F_{j}=$ The value of the principal component (factor) as a linear combination of observable variables (growth rate of the second-tier bank financial indicators)

$C v_{j}=$ Cumulative dispersion of the principal components eigen-values on the second-tier banks financial stability, \%

$J=$ The number of the principal component values as a linear combination of the observable variables (Khalafyan, 2014)

As is illustrated by the data from Table 2, within the anti-crisis management model in the post-crisis period, the development of the RK baking sector is by $37.1 \%$ predetermined by Factor 1 (F1), which consists of the growth rate of the indicators as follows: Loan portfolio, liabilities, retail deposits, corporate deposits, performing assets (net), net remuneration related income. About $18.7 \%$ account for the growth rate of such financial stability indicators as the intensity of changes in capital adequacy ratio $(\mathrm{k} 1-1)$, capital adequacy ratio $(\mathrm{k} 2)$, ratio of maximum risk exposure per borrower associated with bank special relationships $(\mathrm{k} 3$ '). These indicators form Factor 2 (F2). About $16.1 \%$ of the development is predetermined by the growth rate of the ratio of maximum amount of bank's investment $(\mathrm{k} 6)$, ratio of maxim limit of short-term liabilities to the RK nonresidents $(\mathrm{k} 7)$ and bank capitalization to liabilities ratio to the RK non-residents $(\mathrm{k} 8)$.

Table 1. Factor loadings of principal components of RK second-tier banks' financial stability indicators in the anti-crisis management model in the post-crisis period

\begin{tabular}{|c|c|c|c|c|}
\hline Indexes (standardized values) & Factor 1 & Factor 2 & Factor 3 & Factor 4 \\
\hline Growth rate of capital adequacy ratio (k1-1) & -0.0963 & 0.9017 & -0.0083 & 0.0887 \\
\hline Growth rate of capital adequacy ratio $(\mathrm{k} 2)$ & -0.0373 & 0.9117 & 0.0473 & 0.1403 \\
\hline $\begin{array}{l}\text { Growth rate of maximum risk exposure per borrower, } \\
\text { associated with bank special relationships (k3') }\end{array}$ & -0.0276 & 0.7328 & -0.0990 & -0.0067 \\
\hline Growth rate of the ratio of maximum amount of bank's investment (k6) & 0.1565 & 0.4968 & 0.7526 & 0.1564 \\
\hline Growth rate of ratio of maxim limit of short-term liabilities to the RK non-residents (k7) & -0.0047 & 0.0153 & 0.9227 & -0.0371 \\
\hline Growth rate of ratio of bank capitalization to liabilities to the RK non-residents (k8) & 0.0099 & -0.0294 & 0.9030 & 0.0146 \\
\hline Growth rate of loan portfolio volume & 0.9760 & 0.0476 & -0.0008 & 0.0268 \\
\hline Growth rate of total commitment amount & 0.8645 & 0.0606 & 0.0537 & 0.1350 \\
\hline Growth rate of retail deposits & 0.9636 & 0.0328 & -0.0224 & 0.0502 \\
\hline Growth rate of corporate deposits & 0.9728 & 0.0500 & 0.0137 & 0.0312 \\
\hline Growth rate of performing assets (net) & 0.9672 & 0.0332 & 0.0048 & -0.0490 \\
\hline Growth rate of net remuneration related income & 0.6886 & -0.0908 & -0.0069 & -0.4934 \\
\hline Growth rate of interest margin & -0.0394 & 0.1049 & 0.0338 & 0.8889 \\
\hline Growth rate of interest spread & -0.1551 & 0.1390 & -0.0156 & 0.8621 \\
\hline
\end{tabular}

Table 2. Eigen-values of principal components of RK second-tier banks' financial stability indicators in the anti-crisis management model in the post-crisis period

\begin{tabular}{lcccc}
\hline Factor & Eigen-values & \% of dispersion & Cumulative eigen-values & \% of cumulative dispersion \\
\hline Factor 1 & 4.778 & 37.11 & 4.78 & 37.11 \\
Factor 2 & 2.200 & 18.72 & 6.98 & 55.83 \\
Factor 3 & 1.830 & 16.06 & 8.81 & 71.89 \\
Factor 4 & 1.540 & 14.01 & 10.35 & 85.89 \\
\hline
\end{tabular}

Table 3. The value of the integral indicator of the RK banking system development in the post-crisis period

\begin{tabular}{llllllll}
\hline Period & 2008 & 2009 & 2010 & 2011 & 2012 & 2013 & 2014 \\
\hline The value of the integral indicator & 0.04 & 0.016 & -0.02 & 0.02 & 0.03 & 0.06 & 0.06 \\
\hline
\end{tabular}


As an aggregate, these indicators represent Factor 3 (F3). About $14 \%$ account for the growth rate of the bank profitability and form Factor 4 (F4). In all, the intensity of changes in the abovementioned system of indicators by $85.9 \%$ characterizes the Kazakhstan banking sector financial stability and development in the post-crisis period.

The results of applying the method of principle components made it possible to identify the input priority of the financial stability indicators of the secondtier banks in the anti-crisis management model, ensuring the RK banking sector development in the post-crisis period. Such an approach, by virtue of applying the additive convolution of the principal component values, allows calculating the level of the taxonomical indicator of the banking sector development taking into account the priorities of the effects produced by the second-tier banks' financial stability indicators. The value of the integral indicator of the RK banking system development is presented in Table 3.

The integral indicator of the RK banking system development, as was indicated in this study earlier, is predetermined by the resulting indicator, obtained in calculating the optimum (critical) levels of the secondtier banks' financial stability indicators in the anti-crisis management system in the post-crisis period.

The simulation modeling technique has been applied within the framework of this study to calculate the levels of the bank financial stability in the anti-crisis management model, ensuring the development of the national banking sector in the post-crisis period (Lavrushin, 2015). The statistical base was formed of the growth rate of the absolute indicators and of the quotients of the bank financial stability in 2008-2014, the sampling thereof being formed within this study. The absolute values of the banks' financial stability indicators were corrected applying the inflation index for the relevant period.

Applying the correlation-regression model, the cumulative effect of the components of the banks' standardized financial stability indicators on the resulting indicator (taxonomic indicator of the RK banking sector development in the post-crisis period) has been formalized:

$$
\begin{aligned}
& X 1=-0.0057+1.0110 * X 2+1.0353 * X 3 \\
& X 4=-0.7127+1.4932 * X 5+2.1248 * X 6 \\
& X 7=-2.0367+2.5445 * X 8+0.0274 * X 9+0.9499 * X 10 \\
& +5.1585 * X 11+0.1242 * X 12 \\
& X 13=0.0020+0.7151 * X 14 \\
& Y=-0.1869-0.1474 * X 1-0.1953 * X 2-0.0024 * X 3 \\
& +0.0375 * X 4+0.0041 * X 5+0.0125 * X 6+0.0078 * X 7 \\
& +0.0163 * X 8+0.0001 * X 9+0.0066 * X 10+0.0695 * X 11 \\
& +0.0001 * X 12+1.2001 * X 13+0.9974 * X 14
\end{aligned}
$$

Where:

$Y=$ The value of the integral (taxonomic) indicator of the RK banking system development in 2008-2014
$X 1=$ The standardized value of the capital adequacy ratio $(k 1-1)$

$X 2=$ The standardized value of the capital adequacy ratio $(k 2)$

$X 3=$ The standardized value of the ratio of maximum the risk exposure per borrower associated with bank special relationships ( $\mathrm{k} 3$ ')

$X 4=$ The standardized value of the ratio of maximum amount of bank's investment

$X 5=$ The standardized value of the ratio of maxim limit of short-term liabilities to the RK nonresidents $(k 7)$

$X 6=$ The standardized value of ratio of bank capitalization to liabilities ratio to the RK nonresidents $(\kappa 8)$

$X 7=$ The standardized value of the growth rate of the loan portfolio volume

$X 8=$ The standardized value of the growth rate of the total commitment amount

$X 9=$ The standardized value of the growth rate of the amount of retail deposits

$X 10=$ The standardized value of the amount of corporate deposits

$X 11=$ The standardized value of the growth rate of the performing assets

$X 12=$ The standardized value of the growth rate of the net remuneration related income

$X 13=$ The standardized value of the interest margin

$X 14=$ The standardized value of the interest spread

The resulting indicators $X 1, X 4, X 7, X 13$ in evaluating the cumulative effect within each factor of the second-tier banks' financial stability indicators are determined at the author's discretion. This is justified by the fact that in simulation modeling it does not matter which indicator is perceived as a resulting indicator. It is founded on the level of the cumulative effect within each of the formed factors (principal components) of the second-tier banks' financial stability in the post-crisis period.

Applying the developed equation system of the correlation-regression dependency existing between the level of the RK second-tier banks' financial stability and the national banking system development, the simulation model has been built to calculate the optimum (critical) levels of the RK second-tier banks' financial stability indicators in the anti-crisis management, ensuring the sustainable development of the national banking system in the post-crisis period (Fig. 2).

The model separates the standardized values of the banks' financial indicators in such a way that the value of the integral indicator in the presented multifactor model should be $>0$, because only with the value of the taxonomic quotient of the RK banking sector $>0$ it is possible to maintain that the national banking system in the post-crisis period actually develops. 
Based on the simulation model in Vensim software environment the values of the financial stability relative indicators in the commercial banks of Kazakhstan were calculated, at which the integral indicator of Kazakhstan banking sector development $>0$. Given the fact that the banking institutions are affected by systematic risks, their activities are subordinated and are rigorously controlled by prudential regulations of the RK National Bank, the strict compliance to these regulations being the basis of the anti-crisis management in the commercial banks. Thus, in determining the optimum quantitative levels of the second-tier bank financial indicators the prudential regulations of the RK second-tier banks were taken into account as well (NBRK, 2005).

The calculated values for the optimum levels of the financial stability indicators in the commercial bank anticrisis management are presented in Table 4.

To identify the second-tier banks' financial stability indicators for applying in the process of the absolute value measured monitoring of the banking activity, the optimum intensity levels of their development have been established. That is, for such indicators as the loan portfolio, the liabilities, retail deposits, corporate deposits, the performing assets (net) and the net remuneration related income the simulation model determined the growth rates, at which the integral level of the national banking sector development is $>0$.

The resulting values of the growth rate of the banks' financial stability absolute indicators, ensuring the RK banking system development are presented in Table 5 .

The optimum level of the second-tier banks' financial stability is a quantitative criterion for evaluating the efficiency of realizing the social and technical tactical tasks in the anti-crisis management model. It is exactly the social and economic component that should ensure the optimum level of the financial stability, stipulating, by means of applying the anti-crisis management model, the national banking system development in the post-crisis period.

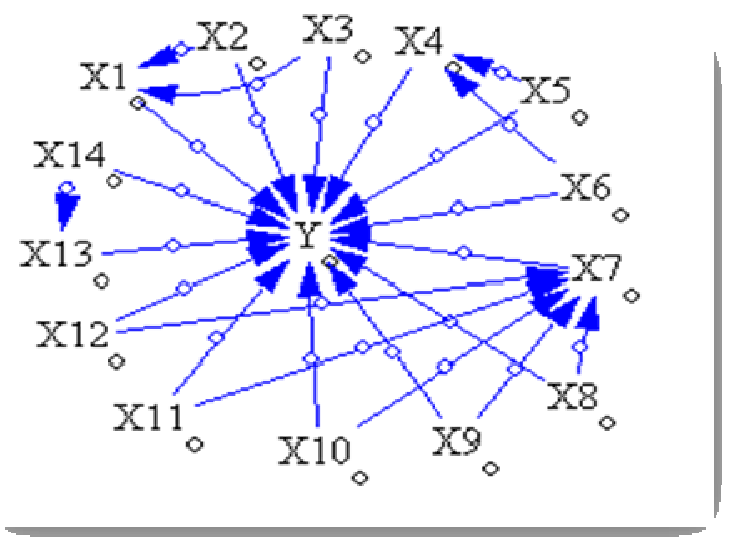

Fig. 2. Simulation model for calculating the optimum (critical) levels of the RK second-tier banks' financial stability indicators in the post-crisis period

Table 4. Optimum (critical) values of the RK second-tier banks' financial stability indicators in anti-crisis management model providing the national bank system development in the post-crisis period

\begin{tabular}{|c|c|c|c|}
\hline Indicators & $\begin{array}{l}\text { Optimum values } \\
\text { of the indicator }\end{array}$ & $\begin{array}{l}\text { Effective vector of } \\
\text { the indicator change }\end{array}$ & $\begin{array}{l}\text { The range of values providing } \\
\text { the potential development } \\
\text { including standard values }\end{array}$ \\
\hline Capital adequacy ratio $(\mathrm{k} 1-1)$ & 0.25 & Decrease & $0.06-0.25$ \\
\hline Capital adequacy ratio (k2) & 0.18 & Decrease & $0.12-0.18$ \\
\hline $\begin{array}{l}\text { Ratio of maximum risk exposure per borrower, } \\
\text { associated with bank special relationships (k3') }\end{array}$ & 0.13 & Decrease & - \\
\hline Ratio of maximum amount of bank investment (k6) & 0.35 & Increase & $0.35-0.5$ \\
\hline $\begin{array}{l}\text { Ratio of maximum limit of short-term liabilities to the } \\
\text { RK non-residents }(\mathrm{k} 7)\end{array}$ & 0.025 & Increase & $0.025-1$ \\
\hline $\begin{array}{l}\text { Ratio of bank capitalization to liabilities to the } \\
\text { RK non-residents }(\mathrm{k} 8)\end{array}$ & 0.35 & Increase & $0.35-2$ \\
\hline Interest margin & $3.7 \%$ & Increase & - \\
\hline Interest spread & $2.8 \%$ & Increase & - \\
\hline
\end{tabular}


Table 5. Optimum (critical) levels of growth rate for the absolute financial indicators of the RK second-tier banks in anti-crisis management model providing the national bank system development in the post-crisis period

\begin{tabular}{lll}
\hline Indicator & $\begin{array}{l}\text { Optimum level } \\
\text { of growth rate }\end{array}$ & $\begin{array}{l}\text { Effective vector } \\
\text { of the indicator change }\end{array}$ \\
\hline Loan portfolio & 1.03 & Increase \\
Commitments & 1.03 & Increase \\
Retail deposits & 1.02 & Increase \\
Corporate deposits & 1.04 & Increase \\
Performing assets (net)) & 1.06 & Increase \\
Net remuneration related income & 1.01 & Increase \\
\hline
\end{tabular}

\section{Discussion}

The findings allowed forming a multidisciplinary model of crisis management in the Kazakhstan secondtier banks, capable of ensuring rapid development of the national banking system in the post-crisis period. The basis for the formation of the model as opposed to the existing methodology of strategic management is an integrated approach as a strategic objective is achieved not only with account for the economic factor, but also taking into account of the subordination of economic and socio-technical factors. The calculated values of the optimal level of financial stability should be a vector to achieve the efficiency of formation and solution of socio-technical tactical goals of crisis management.

According to the developed planning chart, the crisis management of second-tier banks in post-crisis period should initially focus on the resolution of tactical tasks of staff, namely:

- Improving the staff quality through collaboration with leading foreign institutions, the introduction of distance learning technologies and benchmarking processes, the introduction of national standards for training bank staff. This approach will contribute to the realization of tactical objectives for the development of the bank and customers' retention of the bank due to the ability of staff to the real-time analysis to make intelligent decisions to stimulate sales

- The increase of staff loyalty by taking into account the views of employees in the bank management decisions and the implementation of the principle and the uniqueness of the rules in the workplace and improving the quality of relations with the bank's management staff. The increase of loyalty will form the development of an individual approach to the clients of the bank, which will also contribute to the client base development and retention

- Professional development and loyalty of employees of the bank as part of a multi-disciplinary anti-crisis management model will generate competent advice for the integration of risk management in second-tier banks in accordance with the requirements of the Basel Committee. This, in turn, will ensure that the bank's capital adequacy ratio as an indicator of financial stability of the organization
Tactical purposes of crisis management in the area of improving business processes, especially in the postcrisis period should be focused on the development of multi-channel network and reduction of physical points of customer service by increasing client network of banks for the consulting services of the population, digitalization of banking services, the development of a unified history of client communication, the introduction of innovative products and cross-selling; developing a centralized system of account management and rights for the Information Resource access. This approach will ensure the development of communications with clients of RK second-tier banks and individual approach to customers, which in turn will contribute to the development of the client base.

The main tactical purpose, in the present crisis management model in banks of Kazakhstan in the postcrisis period in the block of "clients" problems is the development and retention of the bank clients, which is provided by the development of the bank positive image, the development of an individual approach to the bank clients, the use of real-time analysis for intelligent solutions for sales promotion, the development of the bank's agent network for population consulting services.

The development and retention of the bank client base will serve as a basis for the implementation of tactical tasks of a higher order of the "Finance" block-the increase of RK second-tier banks' financial stability.

Simulation results yielded values of RK second-tier banks' financial indicators, which reflect the level of financial stability of the banking system, which provides the rapid development in the post-crisis period. It should be noted that these levels of performance as opposed to modern methods of evaluation and analysis of the banks' financial stability as part of crisis management reflect an accurate assessment of the bank as they are calculated taking into account the market evaluation of balance sheet items when determining the financial stability indicators. Accounting for inflation index provides an objective meaning and allows objectively reflecting the actual financial condition of the commercial second-tier banks and the potential of the national banking system development in the post-crisis period. Besides, when counting values of financial stability based on the actual financial statements of RK second-tier banks of 
Kazakhstan such disadvantage in the methods of crisis management as the subjective assessment of exports and ignoring the level of development of the national banking sector that is inherent in the coefficient and rating procedures is eliminated.

Based on these results it can be stated that the implementation of tactical tasks of socio-technical component of crisis management system in the RK commercial banks should ensure capital adequacy ratio (k1-1) at a level not exceeding 0.25 , but not less than 0.06. Capital adequacy ratio (k2) must not be higher than 0.18 and not less than 0.12. Compliance of banks with the capital adequacy level within the designated range will enhance the effectiveness of the bank activity as it limits a significant increase of the idle equity and determines its capitalization. Besides maintaining optimal levels of the capital adequacy contributes to a necessary minimum amount of equity capital for the leveling of unforeseen financial losses without the threat of damage to its clients and the deterioration of asset quality. Since the foundation of financial stability of commercial banks is the active efficiency of operations, the approximate value of these financial indicators to the standard 0.06 will provide the maximum effect to increase the bank stability.

The ratio of maximum risk exposure per borrower, associated with bank special relationships (k3') must not exceed the level of 0.13 . The increase in the optimal level of these financial ratios will serve as a deterrent factor for the banking system development and the decrease will determine the potential development. Compliance with this level of risk by the RK banks downwards will promote the quality of loan portfolio of financial institutions and the possibility of effective generation of bank loan resources, will form the basis of increase excluding the risk capacity of economy lending in the post-crisis period.

The ratios of maximum amount of investment of the commercial banks (k6) must not fall below 0.35 , which will promote utilization of the investment risks of financial institutions and determine banks' financial stability preservation.

The optimal level of bank capitalization to liabilities to RK non-residents $(\mathrm{k} 8)$ ranges from 0.35 to 2 . The ratio of maximum limit of short-term liabilities to RK nonresidents (k7) must not fall below 0.025 , but it is limited to standard value increase 1. Optimal range of these indicators will enable forming bank currency reserves and increase the effectiveness of regulation bank liabilities pattern.

Socio-technical factors of anti-crisis management should ensure the bank interest margin of at least 3.7\% and the interest rate spread of not less than $2.8 \%$. This level of indicators demonstrates the effectiveness of the banks' active operations. The increase in profitability will contribute to the sustainability of its own equity generation by banks as a factor of the organization's financial stability, an increase in the liquidity of its assets and the utilization of the systemic risks threat. Only by compliance with this level of profitability provides the development and sustainability of the national banking system in the post-crisis period.

The loan portfolio volume and the amount of joint liabilities of second-tier banks will ensure the growth of the national banking system only if the annual growth is not less than $103 \%$. The annual growth of these indicators will testify about banks' activity in the process of formation of temporarily free cash by business entities. Under conditions of monopoly on the formation of the cost of loan capital in Kazakhstan's economy, the growth of the second-tier banks' loan portfolio will be a defining factor not only of the increase of the national banking system well-being, but the increase in business activity in the economy.

The amount of the retail deposits in the accounts of commercial banks should be ensured by the growth rate of not less than $102 \%$ per year and corporate deposits$104 \%$. This level of these indicators will contribute to the generation of high-quality pattern of banks' liabilities, the possibility of capitalization of the loan capital and improve the profitability of banking operations. It will help improve the investment attractiveness of the position of banks from the standpoint of foreign investors and increase the value of bank assets.

Assuming the annual growth rate of second-tier banks' net assets are not lower than $106 \%$ and net income of not less than $101 \%$ a year, the prerequisites for the second-tier banks' sustainability to the threats of the external environment are formed. Ensuring the growth of these indicators leads to improving banks' efficiency, as they are the result of the dominance of active bank operations over their liabilities, enhance the bank's reliability level and potentially shape the growth of functioning assets and minimize non-performing assets of the bank, which implies the cumulative increase in their profitability.

Thus, the achievement of a critical level of the RK second-tier banks' financial stability indicators through the implementation of socio-technical tactical goals in the crisis management system will provide the maximum intensity of the banking system development in the postcrisis period and therefore the implementation of the strategic objective.

Thus, the developed multidisciplinary model of crisis management in RK banks in the post serves as a basis for improvement of theoretical and methodological foundations of the financial management of crisis in banks. Unlike existing methods of assessing the banks' financial stability as part of crisis management the presented approach is characterized by objectivity and correctness of the results, is based on the interaction and 
subordination of economic, social and technical factors of anti-crisis management takes into account the specificity of the post-crisis period of the banking system functioning, as well as enables determining the financial stability level providing the intensive development of the banking system taking into account tactical problems of socio-economic subsystem of anti-crisis management.

The findings from the framework for further research in this area, in particular the study and formation of the optimal models of governance in the RK banking system in the post-crisis period.

\section{Conclusion}

Within the framework of an empirical study based on its results, the following conclusions were obtained.

The study developed a multidisciplinary model of crisis management in RK second-tier banks. A distinctive advantage is its determination of cause and effect relationship of anti-crisis methods (tactical objectives) based on subordination of economic (financial) and socio-technical component of crisis management system in order to achieve the strategic goal-ensuring the development of the national banking system in the post-crisis period.

By simulation the critical (optimum) levels of the second-tier banks' financial stability indicators were calculated, the achievement of which must be provided by the socio-technical methods of anti-crisis management model. Achieving the optimal level and compliance with commercial banks' financial stability level will testify to the effectiveness of anti-crisis measures concerning staff, clients and bank business processes, which is the condition of intensive development of the national banking system in the post-crisis period.

It is proved that the possibility of an objective determination of critical levels of the banks' financial stability in anti-crisis management model is an indicator of the novelty represented by a conceptual approach regarding the generally accepted methods, based on the rating and export estimates. The possibility of incorporating the actual state and potential development of the national banking system, as well as prioritizing the influence of banks' financial stability indicators on the growth rate of the banking system characterize its advantage relating to coefficient methods of banks' financial stability assessment in the anti-crisis management system.

The developed multidisciplinary model of anti-crisis management is destined to improve the theoretical and methodological foundations of the system of commercial banks' anti-crisis management and a tool for the RK banking system sustainable development in the postcrisis period. It is characterized by simplicity, versatility and promotes sound prioritization of crisis management in the banking sector in the post-crisis period.

\section{Acknowledgement}

The authors gratefully acknowledge support of the Karaganda State University named after academician E.A. Buketov in conducting the present research.

\section{Author's Contributions}

Leile Syzdykovna Komekbayeva: Developed the plan of the research and carried out the study, data collection of the study sample, analysis and writing of the manuscript.

Yerkenazym Dulatovna Orynbassarova: Participated in the results analysis, contributed to the drafting of the article and provided critical reviewing for significant intellectual content.

\section{Ethics}

This article is original and contains unpublished material. The corresponding author confirms that all of the other authors have read and approved the manuscript and no ethical issues involved.

\section{References}

ABRK, 2013. The concept of development of the financial sector of the Republic of Kazakhstan till 2030. The Resolution of the Government of the Republic of Kazakhstan, The Association of Banks of the Republic of Kazakhstan.

Ahrend, R. and A. Goujard, 2015. Global banking, global crises? The role of the bank balance-sheet channel for the transmission of financial crises. Eur. Econom. Rev., 80: 253-279.

DOI: $10.1016 /$ j.euroecorev.2015.10.003

Asmild, M. and M. Zhu, 2015. Controlling for the use of extreme weights in bank efficiency assessments during the financial crisis. Eur. J. Operat. Res., 251: 999-1015. DOI: 10.1016/j.ejor.2015.12.021

Bhat, G. and S.G. Ryan, 2015. The impact of risk modeling on the market perception of banks' estimated fair value gains and losses for financial instruments. Account., Organ. Society, 46: 81-95. DOI: 10.1016/j.aos.2015.04.004

Bigeldyieva, Z., B. Shoraev, Z. Kudaibergenova, N. Saripbekova and A. Aitimbetova et al., 2014. Perfection of government control of bank activity is in republic of Kazakhstan. Proc. Soc. Behav. Sci., 143: 595-598.

DOI: $10.1016 /$ j.sbspro.2014.07.443

Caggiano, G., P. Caliceand and L. Leonida, 2014. Early warning systems and systemic banking crises in low income countries: A multinomial logit approach. J. Bank. Finance, 47: 258-269.

DOI: $10.1016 /$ j.jbankfin.2014.07.002 
Dungey, M. and J. Lestano, 2015. The internationalisation of financial crises: Banking and currency crises 1883-2008. North Am. J. Econom. Finance, 32: 29-47. DOI: 10.1016/j.najef.2015.01.003

Fernández, A.I., F. González and N. Suárez, 2013. The real effect of banking crises: Finance or asset allocation effects? Some international evidence. J. Bank. Finance, 37: 2419-2433. DOI: 10.1016/j.jbankfin.2013.02.012

Fiedor, P., 2014. Sector strength and efficiency on developed and emerging financial markets. Phys. A: Stat. Mech. Applic., 413: 180-188. DOI: 10.1016/j.physa.2014.06.066

Frey, R. and C. Kerl, 2015. Multinational banks in the crisis: Foreign affiliate lending as a mirror of funding pressure and competition on the internal capital market. J. Bank. Finance, 50: 52-68. DOI: 10.1016/j.jbankfin.2014.06.005

Jovanovic, B. and M. Petreski, 2014. Monetary policy, exchange rates and labor unions in SEE and the CIS during the financial crisis. Econom. Syst., 38: 309-332. DOI: 10.1016/j.ecosys.2013.12.005

Kašparovská, V., J. Gláserová and J. Laštůvková, 2014. An evaluation of the readiness for the implementation of the IFRS 13 standard and its impacts on the financial reporting of the banks. Proc. Econom. Finance, 12: 288-295. DOI: $10.1016 / \mathrm{S} 2212-5671(14) 00347-5$

Khalafyan, A.A., 2014. STATISTICA 6. Statistical Data Analysis. 1st Edn., Binom-Press, Moscow, pp: 607.

Kolbin, V.V., 2015. Mathematical Methods of Collective Decision-Making. 1st Edn., Lan, St. Petersburg, pp: 256.

Kravchenko, D.V., 2015. Financial and Legal Regulation of the Banking Sector: A Comparative Legal Aspect. 1st Edn., Monograph, Prospect, Moscow, pp: 144.

Kuchukova, N.K., S.B. Makysh and K.Z. Sadvokasova, 2013. The Modernization of the Financial System of Kazakhstan in the Context of Financial Globalization. 1st Edn., Monograph, Master PO, Astana, pp: 366.

Lavrushin, O.I., 2015. New Models of Banking Activities in the Modern Economy. 1st Edn., Monograph, KnoRus, Moscow, pp: 168.

Ibrahim, M.H., 2016. Business cycle and bank lending procyclicality in a dual banking system. Econom. Modell., 55: 127-134.

DOI: 10.1016/j.econmod.2016.01.013

Marchenko, G.A., 2010. The banking system of Kazakhstan: The lessons of the crisis. Money Credit, 4: 27-29.
Marín Hernández, S., E. Gras Giland M. Anton Renart, 2015. Spanish credit institutions: Do efficiency and solvency support the first decisions on bank restructuring from a financial point of view 20082012? Contaduría Admin., 60: 367-388. DOI: $10.1016 / \mathrm{S} 0186-1042(15) 30005-\mathrm{X}$

Markman, G.M. and M. Venzin, 2014. Resilience: Lessons from banks that have braved the economic crisis-and from those that have not. Int. Bus. Rev., 23: 1096-1107. DOI: 10.1016/j.ibusrev.2014.06.013

Mayer, A., 2013. The possibility of applying mathematical modeling to optimize the structure and the financial stability of the credit system of the Republic of Kazakhstan. Actual Prob. Econom., 3: 360-369.

MNERK, 2015. The official Internet resource of the Ministry of National Economy of the Republic of Kazakhstan. Statistics Committee.

NBK, 2015. Official Internet resources of the National Bank of the Republic of Kazakhstan.

NBRK, 2005. On approval of the Instruction on standard values and methods of calculation of prudential standards for second-tier banks. The Resolution of the Board of the Agency of the Republic of Kazakhstan on Regulation and standards for secondtier banks. National Bank of the Republic of Kazakhstan.

Rakhmetova, A.M., 2015. Innovations as a factor of optimization of interrelations between banking and real sectors of the economy in the present conditions. Russ. J. Entrepreneurship, 16: 1297-1314. DOI: $10.18334 /$ rp.16.9.218

Ritz, R.A. and A. Walther, 2015. How do banks respond to increased funding uncertainty? J. Finan. Int., 24: 386-410. DOI: 10.1016/j.jfi.2014.12.001

Vazquez, F. and P. Federico, 2015. Bank funding structures and risk: Evidence from the global financial crisis. J. Bank. Finance, 61: 1-14. DOI: 10.1016/j.jbankfin.2015.08.023

Zhu, X., Y. Xie, J. Li and D. Wu, 2015. Change point detection for subprime crisis in American banking: From the perspective of risk dependence. Int. Rev. Econom. Finance, 38: 18-28. DOI: $10.1016 /$ j.iref.2014.12.011 